\title{
A Segmental Chronic Pain Syndrome in Rats Associated with Intrathecal Infusion of NMDA: evidence for selective action in the dorsal horn
}

\author{
Douglas W. Zochodne, Marilyn Murray, Sukriti Nag and Richard J. Riopelle
}

\begin{abstract}
We explored the effects of chronic lumbar intrathecal NMDA infusion (mini-osmotic pumps) in Sprague-Dawley rats on motor and sensory axon integrity. Several different infusion protocols, each given over a 4 week period were examined: $0.15 \mathrm{M} \mathrm{NMDA}$ in phosphate buffered saline; phosphate buffered saline without NMDA; and $0.20 \mathrm{M}$ magnesium sulfate plus $0.15 \mathrm{M}$ NMDA; $0.35 \mathrm{M}$ NMDA. In two additional protocols, 0.15 M NMDA or phosphate buffered saline were infused for a total of 8 weeks. Within 1-2 weeks of the onset of NMDA, but not phosphate buffered saline infusions, the rats exhibited irritability, circling, biting and excessive grooming resulting in loss of hair, and skin ulcerations from autotomy localized to lumbar and sacral innervated dermatomes. Co-infusion of NMDA with magnesium sulfate almost completely prevented these findings. The behavioural changes were not associated with abnormalities of sensory or motor conduction. Intrathecal infusion of NMDA induces a chronic "central" experimental pain disorder in rats, localized to the cord segment with the greatest exposure to the infusion, without involvement of peripheral sensory axons and sparing the axonal integrity of anterior horn cells.
\end{abstract}

Résumé: Un syndrome de douleur chronique segmentaire associé à l'infusion intrathécale de NMDA chez le rat: données indiquant une action sélective dans la corne supérieure de la moelle. Nous avons exploré les effets d'une infusion intrathécale chronique de NMDA au niveau lombaire sur l'intégrité des axones sensitifs (pompes mini-osmotiques) chez des rats Sprague-Dawley. Plusieurs protocoles d'infusion différents, tous administrés sur 4 semaines, ont été examinés: NMDA $0.15 \mathrm{M}$ dans un tampon salin phosphaté; un tampon salin phosphaté sans NMDA; NMDA 0.15M et sulfate de magnésium 0.20M; NMDA 0.35M. Dnas deux protocoles supplémentaires, du NMDA $0.15 \mathrm{M}$ ou un tampon salin phosphaté ont été infusés pendant 8 semaines. Après 1 ou 2 semaines d'infusion du NMDA, les rats présentaient de l'irritabilité, des mouvements giratoires, ils mordaient et se toilettaient de façon excessive, causant une perte de poils et des ulcérations de la peau au niveau des dermatomes dont l'innervation est lombaire et sacrée. La co-infusion de NMDA avec du sulfate de magnésium prévenait presque complètement ces manifestations Les changements du comportement n'étaient pas associés à des anomalies de conduction sensitive ou motrice. L'infusion intrathécale de NMDA induit un trouble chronique "central" expérimental de la douleur chez le rat, localisé aux segments de la moelle qui sont les plus exposés à infusion, sans implication des axones sensitifs périphériques et épargnant l'intégrité des cellules de la corne antérieure.

Can. J. Neurol. Sci. 1994; 21: 24-28

"Central" pain disorders are known to arise in man from lesions at varying levels of the neuraxis including cortex, central white matter, thalamus, brainstem and spinal cord. The dorsal horn of the spinal cord is the initial central purveyor of nociceptive information and there is considerable evidence of plastic alterations in its structure and function following peripheral nociceptive activation. ${ }^{1}$ There is less information about what mechanisms might allow it to become a primary generator of "pain" in the absence of peripheral nociceptive influences. Candidate neurotransmitter agents involved in the local generation of dorsal horn nociceptive volleys would undoubtedly include glutamate, aspartate, Substance P (SP) and calcitonin gene-related peptide (CGRP). The participation of NMDA receptors in this local circuitry has been indicated by direct activation of nociceptive dorsal horn neurons by NMDA and the observation that NMDA receptor antagonists block nociceptive

From the Department of Clinical Neurosciences (D.W.Z.), University of Calgary, Calgary. Alberta, and the Departments of Medicine (M.M. R.J.R.) and Pathology (S.N.), Queen's University, Kingston, Ontario.

RECEIVED MAY I8, 1993. ACCEPTED SEPTEMBER 30, 1993.

Reprint requests to: Dr. Douglas W. Zochodne, University of Calgary, Department of Clinical Neurosciences and the Neuroscience Research Group. Division of Clinical Neurosciences, Heritage Medical Building, 3330 Hospital Drive N.W., Calgary. Alberta, Canada $\mathrm{T} 2 \mathrm{~N} 4 \mathrm{Nl}$ 
inputs. ${ }^{2.3}$ Dorsal horn neurons undergo polysynaptic excitation by both excitatory amino acids acting on NMDA receptors and by peptides, acting together in a synergistic fashion. ${ }^{4}$

In mice, single intrathecal injections of NMDA induced behavioural changes suggesting nociceptive activation..$^{5.6}$ The longer term consequences of NMDA excitotoxin action on the dorsal horn have not been explored. In previous work, we (SN and RJR) examined histological consequences of chronic NMDA infusions in rats. ${ }^{7}$ Local changes at the site of infusion included segmental gliosis and necrosis, with higher doses, of both anterior and posterior horn neurons.

In this work, we studied long term (4 and 8 week) behavioural and electrophysiological consequences of intrathecal NMDA infusions. Chronic central nociceptive activation was assessed by daily examination of the rats for evidence of irritability and autotomy. Serial in vivo and endpoint in vitro measurements of multifibre myelinated motor and sensory conduction and unmyelinated sensory conduction were made. These studies assessed possible peripheral mechanisms of nociceptive pathway activation and the physiological integrity of motor axons. NMDA was delivered by mini-osmotic pumps alone or with magnesium sulfate and compared to control infusions of phosphate buffered saline. Infusions with magnesium indicated whether the action of NMDA could be prevented by blocking the NMDA receptor. We addressed the following questions: (i) what is the dermatomal distribution of autotomy and its time course following intrathecal NMDA? (ii) is the NMDA action blocked by magnesium? (iii) do abnormalities in peripheral conduction, especially sensory myelinated and unmyelinated fibres, account for the behavioural changes? (iv) is there excitotoxic damage to anterior horn cells or neurofilament synthesis as assessed by electrophysiological indices of motor axon integrity?

\section{METHODS}

The studies were conducted on male Sprague-Dawley rats of initial weight 400-500 g housed in wire or wood shaving floored cages and with free access to rat chow and water. Local approval for the work was given by the Animal Care Committee. Surgical procedures and nerve conduction studies were conducted with the animal anaesthetized with sodium amytal $(80 \mathrm{mg} / \mathrm{kg}$ ip). Under sterile technique, a Silastic (Dow Corning) catheter (I.D. $0.3 \mathrm{~mm}$; O.D. $0.64 \mathrm{~mm}$ ) was introduced through the lumbar 5th and 6th space by a slit in the dura and was fed rostrally through the subarachnoid space such that the solutions from the catheter bathed the dorsal surface of the lumbar enlargement. The other end of the catheter was then connected to a infusate primed mini-osmotic pump (Alzet Alza Corporation, 14 day pump \#2002) containing $200 \mu \mathrm{l}$ and with a flow rate of $0.5 \mu \mathrm{l} / \mathrm{hr}$. The pump and positioned catheter were sutured (Ethicon 4-0 silk) to the paraspinal muscles of the rat and then covered, along with the catheter by the approximated and sutured skin flaps. The pumps were replaced every 2 weeks through the protocol while the animal was under sodium amytal anaesthesia. Multifibre nerve conduction studies of caudal motor and sensory fibres were completed at onset (before pump placement) and 4 weeks or 8 weeks later. At endpoint, the sural and peroneal nerves were resected and placed in an in vitro chamber for measurements of myelinated and unmyelinated conduction at $37^{\circ} \mathrm{C}$. The techniques for in vivo and in vitro conduction have been previously described. ${ }^{8}$

The following infusion protocols in 8-12 rats were used, each given continuously over a 4 week period (Table 1): (i) $0.15 \mathrm{M}$ NMDA in $0.1 \mathrm{M}$ phosphate buffered saline (PBS); (ii) $0.1 \mathrm{M}$ PBS alone; (iii) $0.2 \mathrm{M}$ magnesium sulfate together with $0.15 \mathrm{M}$ NMDA for 4 weeks; (iv) $0.35 \mathrm{M}$ NMDA in PBS. Two further infusions were given over 8 weeks: (v) 0.15 M NMDA in PBS; (vi) PBS alone. Studies (i) through (iii) were completed together over a common time period. All rats in these groups were reared on wire cages whereas (iv), (v) and (vi) were reared in plastic shavings-covered shoeboxes. Study (iv) was conducted separately in smaller groups of rats $(n=3)$ since a higher dose of NMDA was employed and included its own control group that received intrathecal PBS alone. Rats were inspected daily (excepting weekends) for evidence of autotomy.

Statistical calculations included determination of means and standard errors. Endpoint studies were compared among the groups using one way analysis of variance at endpoint (ANOVA) for studies (i) through (iv) and by the Student's t test for study $(v)$. The null hypothesis was rejected for $p<0.05$.

\section{RESULTS}

\section{Behavioural Alterations}

Behavioural changes were noted within 1-2 weeks of the onset of infusions. These consisted of irritability, especially when the hindlimbs were handled, circling, excessive grooming of the hindquarters, and chewing or biting of the hindquarters. Later effects were hair loss over portions of the hindquarter and skin lesions from self biting. The autotomy lesions, noted between 7 and 26 days were confined to the lumbar and sacral segmental sensory supply and generally did not involve the upper body, or upper limbs except when higher doses of NMDA $(0.35 \mathrm{M})$ were used. The most common lesion involved the skin over the junction between the hindtrunk and tail. The rats were observed to chew and bite this area within a few days of the start of infusion. Hair loss over the area preceded skin ulceration. The behavioural changes occurred earlier in rats given $0.35 \mathrm{M}$ NMDA than those that received $0.15 \mathrm{M}$ NMDA. In the first 3 groups of animals studied simultaneously (see above) the incidence of autotomy, defined as animals with open skin ulcerations, was 6 out of 12 rats receiving $0.15 \mathrm{M} \mathrm{NMDA}$ for 4 weeks, none out of 11 rats receiving PBS alone for 4 weeks, and 1 out of 7 rats who were co-infused with NMDA and magnesium sulfate.

Table 1. Final Weights.

\begin{tabular}{llc}
\multicolumn{1}{c}{ Group } & n & Weight (grams) \\
\hline Control PBS (4 weeks) & 11 & $537 \pm 17$ \\
0.15 M NMDA (4 weeks) & 10 & $502 \pm 15$ \\
0.15 M NMDA + 0.2 M & & \\
MgSO (4 weeks) & 7 & $530 \pm 9$ \\
Control PBS (8 weeks) & 8 & $577 \pm 18$ \\
0.15 M NMDA (8 weeks) & 9 & $574 \pm 9$ \\
Control PBS (4 weeks) & 2 & $462 \pm 22$ \\
0.35 M NMDA (4 weeks) & 3 & $468 \pm 35$ \\
\hline
\end{tabular}

Values are means \pm SEM 


\section{In Vivo and In Vitro Multifibre Conduction}

The results of serial multifibre in vivo measurements of caudal nerve action potential amplitudes are given in Figure 1 for control animals (0.1 M PBS infusate) and those given NMDA. At all time points, caudal sensory conduction velocities and nerve action potential amplitudes were similar between controls and those given NMDA. In both groups there were expected maturational increases in these indices with time. Rats given a combination of $0.15 \mathrm{M}$ NMDA with $0.2 \mathrm{M}$ magnesium sulfate also had caudal sensory studies that were similar to controls.

The results of in vitro measurements of sural myelinated and unmyelinated fibres are given in Table 2 . As in the in vivo measurements, NMDA infusion was not associated with loss of sural sensory fibres or changes in conduction velocity.

The results of in vivo measurements of caudal and sciatic-tibial motor conduction are given in Figures 2 and 3. Motor conduction velocities in both caudal and sciatic tibial territories were maintained in NMDA treated animals. There was no evidence of motor unit loss as gauged by the amplitudes of the compound muscle action potentials in dorsal foot and caudal muscles. Results of in vitro measurements of peroneal motor conduction are given in Table 3: as in the in vivo studies, peroneal myelinated and unmyelinated fibres were not altered by NMDA infusion. Results were again comparable to those of control animals.

High dose $(0.35 \mathrm{M})$ NMDA infusion over 4 weeks did not alter caudal sensory, caudal motor, sciatic-tibial motor, sural myelinated, sural unmyelinated, or peroneal myelinated conduction when compared to control PBS infused rats.

\section{Discussion}

The major findings of this work were: (i) rats infused with intrathecal NMDA developed adversive behavioural reactions followed over a few days by self-injury or autotomy in the hindquarter skin appropriate to the spinal cord level exposed to the agent; (ii) autotomy was not associated with carrier infusion alone; (iii) autotomy was largely prevented by co-infusion of NMDA with magnesium sulfate; (iv) NMDA infusion was not associated with defects in myelinated and unmyelinated sensory conduction or motor conduction in the hindlimb or tail.

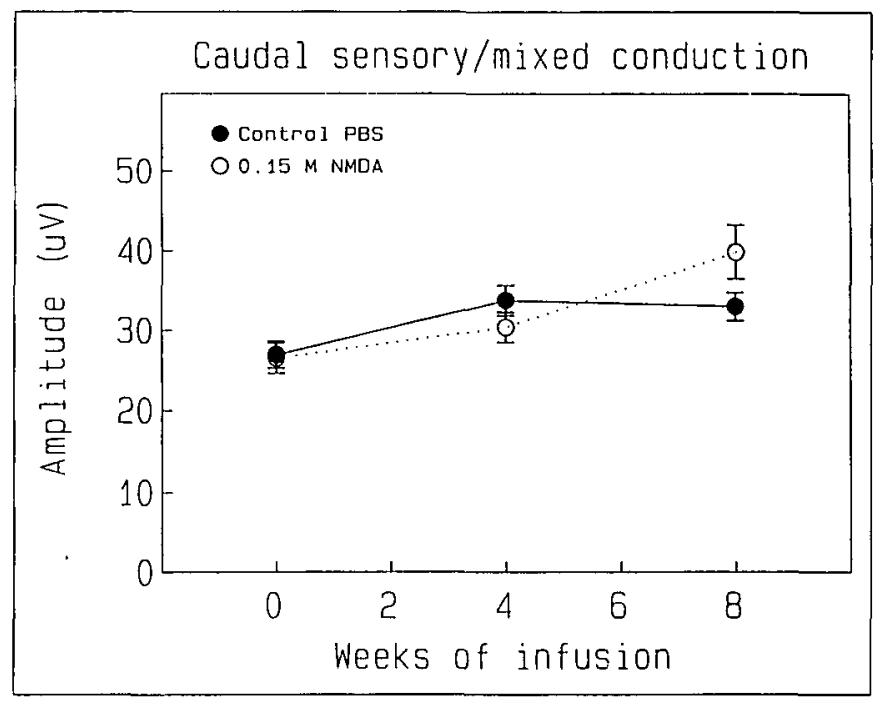

Figure 1: Serial in vivo compound nerve action potential amplitudes from caudal fibres.



Figure 2: Serial in vivo compound muscle action potential amplitudes from caudal and sciatic - tibial fibres.

Table 2. Sural In Vitro Conduction.

\begin{tabular}{|c|c|c|c|c|}
\hline \multirow[t]{2}{*}{ Group } & \multicolumn{2}{|c|}{ Myelinated Fibres } & \multicolumn{2}{|c|}{ Unmyelinated Fibres } \\
\hline & $\mathrm{CV}(\mathrm{m} / \mathrm{s})$ & $A m p(m V)$ & $\mathrm{CV}(\mathbf{m} / \mathbf{s})$ & $\operatorname{Amp}(\boldsymbol{\mu V})$ \\
\hline $\begin{array}{l}\text { Control PBS } \\
\text { (4 weeks) }\end{array}$ & $\begin{array}{l}62.8 \pm 4.8 \\
(9)\end{array}$ & $\begin{array}{c}2.67 \pm 1.20 \\
(9)\end{array}$ & $\begin{array}{c}1.05 \pm 0.09 \\
(7)\end{array}$ & $\begin{array}{l}57 \pm 13 \\
(7)\end{array}$ \\
\hline $\begin{array}{l}0.15 \text { M NMDA } \\
\text { (4 weeks) }\end{array}$ & $\begin{array}{l}57.1 \pm 2.9 \\
(8)\end{array}$ & $\begin{array}{c}2.01 \pm 0.40 \\
(8)\end{array}$ & $\begin{array}{c}1.14 \pm 0.09 \\
(8)\end{array}$ & $\begin{array}{l}62 \pm 16 \\
(7)\end{array}$ \\
\hline $\begin{array}{l}0.15 \mathrm{M} \mathrm{NMDA}+0.2 \mathrm{MgSO}_{4} \\
(4 \text { weeks) }\end{array}$ & $\begin{array}{l}50.6 \pm 4.3 \\
\quad(5)\end{array}$ & $\begin{array}{c}0.89 \pm 0.20 \\
(5)\end{array}$ & $\begin{array}{l}0.85 \pm 0.58 \\
(5)\end{array}$ & $\begin{array}{c}29 \pm 9 \\
(5)\end{array}$ \\
\hline $\begin{array}{l}\text { Control PBS } \\
\text { (8 weeks) }\end{array}$ & $\begin{array}{c}50.6 \pm 3.2 \\
(7)\end{array}$ & $\begin{array}{c}1.54 \pm 0.16 \\
(7)\end{array}$ & $\begin{array}{l}1.09 \pm 0.05 \\
\quad(6)\end{array}$ & $\begin{array}{l}39 \pm 5 \\
(6)\end{array}$ \\
\hline $\begin{array}{l}0.15 \text { M NMDA } \\
\text { ( } 8 \text { weeks) }\end{array}$ & $\begin{array}{l}52.2 \pm 3.5 \\
(9)\end{array}$ & $\begin{array}{c}1.45 \pm 0.43 \\
(9)\end{array}$ & $\begin{array}{l}1.07 \pm 0.12 \\
\quad(4)\end{array}$ & $\begin{array}{c}43 \pm 21 \\
(4)\end{array}$ \\
\hline
\end{tabular}


Table 3. Peroneal In Vitro Conduction.

\begin{tabular}{|c|c|c|c|c|}
\hline \multirow[t]{2}{*}{ Group } & \multicolumn{2}{|c|}{ Myelinated Fibres } & \multicolumn{2}{|c|}{ Unmyelinated Fibres } \\
\hline & $\mathrm{CV}(\mathrm{m} / \mathrm{s})$ & $\operatorname{Amp}(\mathbf{m V})$ & $\mathrm{CV}(\mathrm{m} / \mathrm{s})$ & $\operatorname{Amp}(\mu \mathrm{V})$ \\
\hline $\begin{array}{l}\text { Control PBS } \\
(4 \text { weeks) }\end{array}$ & $\begin{array}{l}62.9 \pm 3.9 \\
\quad(10)\end{array}$ & $\begin{array}{l}2.01 \pm 0.34 \\
\quad(10)\end{array}$ & & \\
\hline $\begin{array}{l}0.15 \text { M NMDA } \\
\text { (4 weeks) }\end{array}$ & $\begin{array}{l}68.2 \pm 4.8 \\
\quad(9)\end{array}$ & $\begin{array}{l}3.31 \pm 1.07 \\
(9)\end{array}$ & & \\
\hline $\begin{array}{l}0.15 \mathrm{M} \mathrm{NMDA}+0.2 \mathrm{MgSO}_{4} \\
(4 \text { weeks) }\end{array}$ & $\begin{array}{l}45.0 \pm 2.1 \\
\quad(4)\end{array}$ & $\begin{array}{l}1.39 \pm 0.45 \\
\quad(4)\end{array}$ & & \\
\hline $\begin{array}{l}\text { Control PBS } \\
\text { ( } 8 \text { weeks) }\end{array}$ & $\begin{array}{c}54.6 \pm 1.7 \\
(7)\end{array}$ & $\begin{array}{c}2.43 \pm 0.32 \\
\quad(7)\end{array}$ & $\begin{array}{c}1.06 \pm 0.11 \\
(5)\end{array}$ & $14 \pm 4$ \\
\hline $\begin{array}{l}0.15 \mathrm{M} \text { NMDA } \\
(8 \text { weeks })\end{array}$ & $\begin{array}{c}54.3 \pm 3.2 \\
(9)\end{array}$ & $\begin{array}{c}1.72 \pm 0.51 \\
(9)\end{array}$ & $\begin{array}{c}1.06 \pm 0.14 \\
(2)\end{array}$ & $\begin{array}{c}19 \pm 13 \\
(2)\end{array}$ \\
\hline
\end{tabular}

Values are means \pm SEM

( ) bracketed numbers indicate $n$

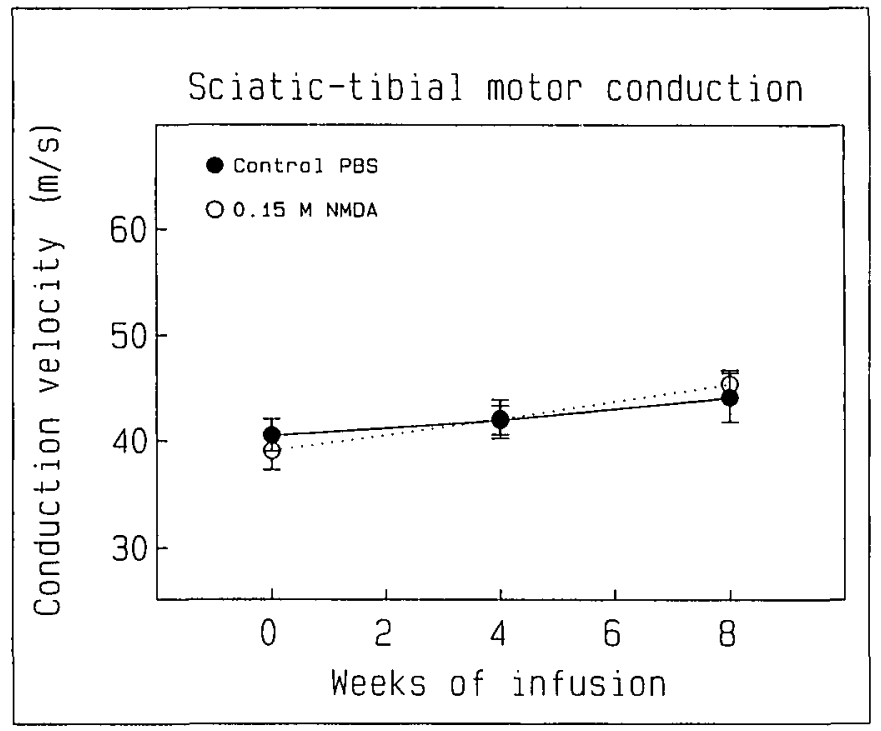

Figure 3: Serial in vivo motor nerve conduction velocities from sciatic tibial fibres.

Several features of the behavioural response to NMDA suggest that its infusion induces an experimental "central" pain disorder, arising from alterations of nociceptive pathways in the lumbar cord. Firstly, the behavioural syndrome appeared to be selectively related to the NMDA receptor because coinfusion with magnesium sulfate largely prevented it. Second, the autotomy lesions and observed biting and chewing reactions were largely confined to the lower hindquarters, i.e., at dermatomes appropriate to the level over which NMDA was infused. Although it is likely that NMDA would have bathed higher cord levels and perhaps cortex, it may have been sufficiently diluted by CSF to prevent action at higher levels. We observed that the onset of autotomy was earlier with the higher dose infusate, arguing in favour of a concentration-dependent mechanism of the local response pattern. Third, the behavioural reaction could not be attributed to peripheral mechanisms because NMDA did not alter peripheral sensory myelinated or unmyelinated conduction. We did not exclude the presence of ectopic afferent activity from sensory nerves or dorsal root ganglia as initiators of a pain syndrome $e^{9,10}$ but think this would be unlikely in the absence of actual damage to these peripheral structures. Models of pain that have evaluated autotomy have previously involved the study of peripheral nerve injury. " We have not excluded sensory root damage as contributing to the pain disorder in this study but are unaware of reports that there could be NMDA receptors on dorsal roots. To fully exclude this mechanism of pain in our model would require appropriate recordings from dorsal roots or their histological examination.

Two central mechanisms could have accounted for this behavioural syndrome in rats: i) chronic activation of nociceptive pathways by an excitotoxic action of NMDA. ii) elimination of antinociceptive interneurons by excitotoxin-mediated cellular necrosis. Both mechanisms have been postulated by Dubner and Ruda. ${ }^{12}$ In favour of the first mechanism was the early onset. In our work the behavioural reaction developed within 1-2 weeks and previous work using mice noted an immediate onset of the adversive behavioural reaction. Aanonsen and Wilcox ${ }^{5}$ and Sakurada et al. ${ }^{6}$ noted that single intrathecal doses of NMDA induced hyperalgesia, and caudally directed scratching and biting behaviour in mice. This behaviour closely resembled that we observed in rats. In mice, an NMDA receptor antagonist (APV), mu opiate agonists, sigma receptor agonists, and phencyclidine all inhibited the behavioural and hyperalgesic effects.

In favour of a mechanism resulting in loss of antinociception is our (SN and RJR) previous histological evidence of localized cord gliosis, and neuronal death in both anterior and posterior horns of the spinal $\operatorname{cord}^{7}$ but this may be a later event, after considerable nociceptor activation has already occurred. Glutamate receptors are particularly distributed in substantia gelatinosa ${ }^{13}$ and glutamate is colocalized with SP (Substance P) in dorsal root ganglion cells. ${ }^{14}$ There seems little reason to believe that glutamate terminals project exclusively to antinociceptive interneurons. Indeed, in experiments in which NMDA was iontophoresed into spinal cord gray matter, not only was there increased firing of a number of wide dynamic range (WDR) lumbar gray matter neurons, but subthreshold doses also increased their firing to peripheral stimulation. ${ }^{2}$ There is also evidence that NMDA antagonists attentuate adversive reactions from peripheral stimuli and block "wind up" activation 
of dorsal horn nociceptive neurons. ${ }^{3.15}$ The release and actions of excitatory amino acids in the dorsal horn are enhanced by peptidergic primary afferent neurotransmitters CGRP and SP: there appears to be close cooperativity between amino acid and peptidergic nociceptive cord circuitry ${ }^{16-18}$ (for review see 4 ). Both SP and serotonin antagonists interrupt NMDA adversive effects. ${ }^{6}$

Peroneal nerve action potential amplitudes (having a major contribution from motor axons), and sciatic-tibial or caudal compound motor action potential amplitudes were preserved despite the use of high doses of NMDA. This is good evidence that the axon processes of anterior horn cells did not atrophy (as would be reflected in reductions of motor conduction velocity) or drop out (as would be reflected in declines in the compound nerve or muscle action potential amplitude) in numbers detectable by our techniques. Since proximal section of a motor nerve is only associated with failure of conduction of distal fibres at an interval of several days, ${ }^{19}$ single exposures of anterior horn cells to excitotoxins, with eventual drop out of these cells, would require up to 2 weeks to be identified. These considerations justified our approach in studying electrophysiological consequences of the infusions at 2 and 4 weeks. In human disorders with gradual loss of anterior horn cells, serial measurements of compound muscle action potentials are sensitive indices of motor unit loss.

How do we correlate the apparent loss of anterior horn neurons in our previous work with these findings? It appears that the dorsal horn consequences of NMDA infusion (nociceptive pathway enhancement) are earlier and more sensitive indices of excitatory amino acid toxicity in the rat. The loss of anterior horn cells may be a relatively late event, could be a retrograde event from loss of dorsal horn interneurons, or might be gradual and mild such that distal sprouting from intact motor units compensates for loss of motor units and preserves the compound muscle action potential. There may have been insufficient injury to the anterior horn cell population to permit detection of decline in the compound muscle action potential. By extending our infusion protocol for 8 weeks, and increasing the NMDA dose we deliberately looked for evidence of a more gradual loss of motor axons from anterior horn cell destruction and tried to accelerate such a process. We did, however, not observe loss of motor axons. Also, the peroneal nerve amplitudes were preserved, arguing against axonal loss. Thus, our findings suggest that anterior horn neurons and their axonal processes are relatively resistant to excitatory toxicity. The absence of electrophysiological evidence for axonal atrophy also suggests that excitotoxin damage does not target somadirected synthesis of neurofilaments, important constituents of cell calibre. The results in this work also clearly differ from electrophysiological features of domoic acid intoxication in humans, a disorder linked to inappropriate activation of glutamate receptors from systemic ingestion. Systemic domoic acid intoxication was associated with evidence of axonopathy, not detected by our intrathecal model. ${ }^{20}$

Of course, to better characterize the motor consequences of amino acid excitotoxicity would require detailed time course studies of anterior horn cell morphology and expression of the appropriate marker molecules on these cells.

\section{ACKNOWLEDGEMENTS}

Lam Ho gave technical assistance and Ellen Wong and Heather Price provided secretarial support. The project was supported by the ALS Foundation of Canada. DWZ received support from the Ontario Ministry of Health as a Career Scientist and is currently a Clinical Investigator of the Alberta Heritage Medical Foundation.

\section{REFERENCES}

1. Wall PD. Neuropathic pain and injured nerve: central mechanisms. Br Med Bull 1991; 47: 631-643.

2. Aanonsen LM, Lei S, Wilcox GL. Excitatory amino acid receptors and nociceptive neurotransmission in rat spinal cord. Pain 1990; 41: 309-321.

3. Dickenson AH, Sullivan AF. Evidence for a role of the NMDA receptor in the frequency dependent potentiation of deep rat dorsal horn nociceptive neurones following $\mathrm{C}$ fibre stimulation. Neuropharmacology 1987; 26: 1235-1238.

4. Willis WD Jr, Coggeshall RE. Sensory Mechanisms of the Spinal Cord. Second Edition. 1991. New York, Plenum Press.

5. Aanonsen LM, Wilcox GL. Nociceptive action of excitatory amino acids in the mouse: effects of spinally administered opioids, phencyclidine and sigma agonists. J Pharmacol Exp Ther 1987; 243: 9-19.

6. Sakurada T, Tan-no K, Manome Y, Sakurada S, Kisara K. Aversive response produced by intrathecal injection of NMDA in mice: effects of substance $\mathrm{P}$ and 5HT antagonists. In: Kameyama, T., Nabeshima, T., Domino, E.F. eds., NMDA Receptor Related Agents: Biochemistry, Pharmacology and Behaviour. Ann Arbor, MI. NPP Books; 1991: 219-225.

7. Nag S, Riopelle RJ. Spinal neuronal pathology associated with continuous intrathecal infusion of N-methyl-D-aspartate in the rat. Acta Neuropathol 1990; 81: 7-13.

8. Zochodne DW, Ho LT. The influence of indomethacin and guanethidine on experimental streptozotocin diabetic neuropathy. Can J Neurol Sci 1992; 19: 433-441.

9. Wall PD, Gutnick M. Properties of afferent nerve impulses originating from a neuroma. Nature $1974 ; 248: 740-743$.

10. Wall PD, Devor M. Sensory afferent impulses originate from dorsal root ganglia as well as from the periphery in normal and nerve injured rats. Pain 1983; 17:321-339.

11. Wall PD, Devor M, Inbal R, et al. Autotomy following peripheral nerve lesions: experimental anaesthesia dolorosa. Pain 1979; 7: 103-113.

12. Dubner R, Ruda MA. Activity-dependent neuronal plasticity following tissue injury and inflammation. Trends Neurosci 1992; 15: $96-103$.

13. Greenamyre JT, Young AB, Penney JB. Quantitative autoradiographic distribution of $\mathrm{L}-[3-\mathrm{H}]$ glutamate-binding sites in the rat central nervous system. J Neurosci 1984; 4: 2133-2144.

14. Battaglia G, Rustioni A. Coexistence of glutamate and substance $P$ in dorsal root ganglion neurons of the rat and monkey. J Comp Neurol 1988; 277: 302-312.

15. Cahusac PMB, Evans RH, Hill RG, Rodriquez RE, Smith DAS. The behavioral effects of an $\mathrm{N}$-methylaspartate receptor antagonist following application to the lumbar spinal cord of conscious rats. Neuropharmacology 1984; 23: 719-724.

16. Dougherty PM, Willis WD. Enhancement of spinothalamic neuron responses to chemical and mechanical stimuli following combined micro-iontophoretic application of $n$-methyl-d-aspartic acid and substance P. Pain 1991; 47: 85-93.

17. Murase K, Ryu PD, Randic M. Excitatory and inhibitory amino acids and peptide-induced responses in acutely isolated rat spinal dorsal horn neurons. Neurosci Lett 1989; 103: 56-63.

18. Woodley SJ, Kendig JJ. Subsance P and NMDA receptors mediate a slow nocieptive ventral root potential in neonatal rat spinal cord. Brain Res 1991; 559: 17-21.

19. Brown WF. The Physiological and Technical Basis of Electromyography. Toronto Butterworth, 1984.

20. Teitelbaum JS, Zatorre RJ, Carpenter $S$, et al. Neurologic sequelae of domoic acid intoxication due to the ingestion of contaminated mussels. N Engl J Med 1990; 322: 1781-1787. 